$$
\begin{aligned}
& S B_{221} \\
& P_{17}
\end{aligned}
$$




\section{LIBRARY OF CONGRESS}

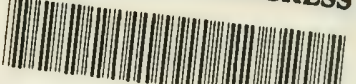
00056857375 00026857375

\section{Hollinger Corp.} $\mathrm{pH} 8.5$ 
[Reprint from Report on Progress of Beet-Sugar Industry in 1902.]

\title{
SINGLE-GERM BEET BALLS AND OTHER SUGGESTIONS FOR IMPROVING SUGAR-BEET CULTURE. ${ }^{a}$
}

\author{
By Trumax G. Palmer.
}

The suggestions made in the accompanying pages for improving some of the methods connected with sugar-beet culture in this conntry are based on personal observations extending over a number of yeurs. In February last I had the honor to suggest to the officials of the Department of Agriculture the idea of producing single-germ beet balls as one means of materially reducing the necesiary quantity of seed, eliminating the labol of thinning and bunching beets, and thereby lowering the cost of producing sugar from beet roots.

While the matter here presented is only suggestive, it is hoped that it may be of value to experimenters and others who are engaged in building up and encouraging an important industry.

TONNAGE AND PRICES OF SUGAR BEETS.

Before treating the subject of increasing the tonnage of sugar beets specifically, an observation as to what is possible of accomplishment from the farmer's standpoint may not be inopportune, although in doing so ground must necessarily be covered which is well known to those who are familiar with the industry.

By experience it has been found that large beets are liable to be low in sugar content, while small beets do not yield sufficient tonnage. A 2-pound beet gives the best average results. Planting in rows 18 inches apart and thimning to $s$ inches grives $13,2.13$ beets to the acre; and if each beet grew to weigh 2 pounds, the yield would he $43 \frac{1}{4}$ tons per acre. This, then, is the maximum yield of ideal-sized beets for' factory purposes.

The average yield in Germany is 12 to 13 tons, in Austria 8.5 to 10 tons, in France 10.75 to 12 tons, in Russia 4.7 to 6.5 tons, while in the United States in 1901 it was 9.6 tons, and in 1902, it was 8.4 tons, both of which figures are undoubtedly below the normal average, as both seasons were unfavorable to beet culture in most sections. Fifteen to 18 tons per acre is not an uncommon yield in some loculities in this country.

$a^{\prime}$ The report from which this is taken is printed in a limited edition, and no copies will be available for general distribution. 
The price of beets in the United States runs from $\$ 3.50$ per ton for a 12 per cent beet up to considerably more than $\$ 5$ for the high-grade beets of some sections.

In portions of Nebraski, for instance, where the beets are rather low in both sugar and purity, the price is necessarily below the arerage, or the factories would be unable to slice them at a profit.

Nature however, recompenses the Nebraska grower, for he is not put to the expense of irrigating as is the case farther west; nor is he compelled to cultivate as extensively as are the beet raisers in some of the more humid States. The factories also recompense the growers by giving them the pulp, which is worth $\$ 1.50$ per ton for feeding purposes.

Owing to the high sugar content and purity, the price of beets in the mountain States and in portions of some other States, is often in excess of $\$ 5$ per ton; but fair conclusions can only be arrived at by using the average tonnage and the average price per ton as a basis.

In 1901 , the arerage price throughont the United States was $\$ 4.50$ per ton. In 1902, the farmers produced a better grade of beets, some of the factories increased the price per ton, and the average was brought up to about $\$ 5$.

With the low average yield of 9.6 tons at $\$ 5$ per ton our farmers receive $\$ 48$ per acre, gross, or a net profit of $\$ 1 s$ per acre if we accept $\$ 30$ per acre as the average cost of production. ${ }^{a}$ As compared to the gross average returns from the culture of our leading cereals, the following figures ${ }^{b}$ are suggestive:

Oats.

\begin{tabular}{|c|r|r}
$\begin{array}{c}\text { Average } \\
\text { yield } \\
\text { per acre. }\end{array}$ & $\begin{array}{c}\text { Average } \\
\text { price per } \\
\text { bushel. }\end{array}$ & $\begin{array}{c}\text { Gross } \\
\text { returus } \\
\text { per acre. }\end{array}$ \\
\cline { 2 - 3 } Bushcls. & & \\
16.7 & $\$ 0.605$ & $\$ 10.10$ \\
15 & .624 & 9.36 \\
25.6 & .452 & 11.57 \\
25.4 & .399 & 10.29
\end{tabular}

If the necessary labor can be greatly reduced and the tonnage doubled or trebled, the anricultural returns in produeing at home the raw sugar, for which in 1901 the United States proper sent abroad more than $\$ 122,000,000$ and for which our people paid the refineries over $\$ 159,000,000$, will be almost heyond estimation.

In America our inventive genius has largely eliminated hand work in both field and factory, and the most serious obstacle to sugar-beet culture is the hand work of thimning the beets after they are planted and of topping them when they are plowed out.

"U. S. Department of Agriculture; Report on the Progress of the Beet-Sugar Industry, 1901, p. 11.

$b$ U. S. Department of Agriculture; Yearbook, 1901, pp. 698-i05. 
The work of perfecting a successful pulling and topping machine to do away with hand work and at the same time save $\$ 5$ to $\$ 8$ per acre in labor has reached the point where several inventor's claim to be absolutely snceessful. In any event, they have so closely approximated it that perfect suceess can be confidently expected within a very few year's. This will leave only the thinning to be done by hand, and it is to the elimination of this remaining hand work that I desire to direct particular attention.

While a perfect-working pulling and topping machine will save much hand lahor and will perhaps slightly increase the tonnage by mole perfectly topping the beets than can be done by hand, to remove the necessity for thimning would not only save a like amount in labor but would result in greatly increasing if not doubling the tonnage.

\section{MULTIPLE-GERM AND SING1L-GERM BEET BALIS.}

The prophecy was recently made by the Secretary of Agrienlture that sugar woukl erentually be produced from American-grown sugar beets at a cost of 2 cents per pound. Such a result is only possible by largely eliminating the hand work in the field and by remoring one of the main causes of low tonnage, namely, the injury inflicted on the remaining roots by the removal of the superfuous ones.

For several years I have realized that if a beet ball could he bred to produee but one plant the difficulties mentioned would he removed; but no one to whom it was mentioned would admit that seience could so radically change the eharacter of plant seed. When the attention of the officials of the Department of Agriculture was called to the subject, they gave it immediate consideration and reached the following conclusions:

(1) That the Department of Agrieulture has overcome far more serious obstacles than those which seem to be involved in the production of single-germ beet balls.

(2) That the desired result would be of great value to the beet-sugar industry.

(3) That a series of experiments looking to the desired end should be inaugurated at once.

Investigations and experiments have already been started by the Department of Agriculture, and it is hoped that the State experiment stations may be led to undertake similar lines of investigation. The first questions involved have to do with the selection of single-germ seed already in existence and then the planting and growing of these seeds to get this characteristic fixed. After this is accomplished, of 
course it will he necessary to follow all of the intricacies of sugar content, size, etc. All of this will take time, and it will undonbtedly require several years before practical results can be attained.

MULTIPLE-GERM BEET BALIS RESPONSIBLE FOR HANI THINNING.

No other work has such an influence on the tonnage as that of thinning. It is the most expensive and laborions work attached to the culture of sugar beets, and to attain the best results it must be most earefully done at the right time.

'This careful labor is necessitated by the peculiar character of the beet seed, which, unlike an ordinary single-germ seed, is really a combination of from one to six seeds, each entirely separate and disconnected from the other's, lut all encased in what is called a "beet ball," an irregular-shaped structure of brittle voody matter about as large as a French pea.

The seeds themselves form but a mere fraction of the ball, the great abundance of woody matter surromding them being provided by nature to aid the germs themselves in various ways. Soaked in water the porous beet ball will absorb 65 per cent of its weight in moisture in twenty-four hours, and when planted in damp ground rapidly draws the moisture to it.

In planting beet seed the beet balls are thickly drilled in rows, the latter usually being 18 inches apart, and the seeds germinate in two to four weeks, depending upon the condition of the soil and weather, while the weed seeds which are only ineased in thin shells are up, far in advance of the beets.

When the seedlings are up and have gained sufficient size to show the third leaf they should be thinned. The thinning can not well be done before this time, and if put off until they are larger the pulling up of the superfluous sprouts injures the roots of those which remain, and the result is a low tonnage. The work is done by people on their hands and knees, who pull up the weeds and all of the beets except the most thrifty one to be found about every $S$ inches. Most of the beet balls send up several sprouts, each of which would make a beet if allowed to grow, and as the beets can not be grown to advantage in clusters, to secure the best results the separation of the tender shoots must be thorough and should be carefully done at the right time, so as not to injure or disturb the roots of the remaining plant. It was this laborious, careful work that led me to suggest the advisability of securing by selection or by breeding a single-germ beet ball which may be drilled a single ball in a place at any desired distance, and as each ball would produce but one seedling or beet the superfluous seedlings could be ent off with a three-cornered hoe instead of being pulled up, thus incurring no dinger of disturbing the roots of those left to make the crop. 
AINANTAGES OF SINGLE-GERM BEET BALLS.

Some of the agrieultural advantages to be gained by seeuring a single-germ heet ball are as follows:

(1) As with reasonable care the removal of the superfluous beets conld not damage any of the roots which are to remain in the ground, a saving of $\$ 1$ to $\$ 2$ an acre in seed could be effected.

(2) To-daly the farmer's sugar-beet acreage is limited to such an area as he can reasonably expect to secure the necessary labor to thin within a given period after the plants shall show the third leaf. Inasmuch as, with a single-germ beet ball the little thinning neessary could be done with a hoe and need not interfere with the remaining roots, and as this work could be extended over a longer period of time, the farmer rould greatly extend his beet plantings with the same amount of availatole labor.

(3) As none of the roots of the remaining beets would be injured hy eareless thimning or not thinning at the proper time, the tonnage per acre woukd be greatly increased.

OBJECTIONS TO SINGLE-GERM BEET BALTS.

After presenting the matter to the Department of Agriculture I laid it before the agricultural experts of each American beet-sugar factory inviting such criticism as might occur to them. Generally speaking, these gentlemen immediately realized the important bearing which such a derelopment would have on the industry. The few objections presented came from territory west of the Missouri River and were as follows:

(1) Owing to the fact that it takes several weeks for a beet seed to germinate and that in the meantime there may be showers or storms, as the result of which the soil may become crusted, fear was expressed that the single beet plants might be unable to break through this erust, whereas clusters of shoots from multiple-germ balls as at present planted do suceeed in breaking through.

(2) The second objection urged was that inasmuch as weed seeds start much earlier than those of the beets, so that the weeds are well advanced when the latter come up, oftentimes surrounding and smothering the heets, there would be much less likelihood of seeuring a good stand where but one seed was planted in a place than where the seeds are thickly drilled in.

As a beet ball will absorb 65 per cent of its weight in moisture within twenty-four hours, and as it must be thoroughly dampened before it will germinate, I can see no good reason why a great portion of this work should not be done prior to planting, instead of waiting for the ball to absorb its full quota of moistrue from the soil.

If the germination can be hastened so that the seedlings are un a 
few days instead of several weeks after planting, the liability of their being unable to get through a soil erusted by showers will be greatly diminished, as, the period between planting and gremination being shortened, the danger from showers will be correspondingly reduced.

As regards weeds, the writer is aware of the fact that a sugar-beet field should be free from weed seed before it is planted to beets, lut such is rarely the cave; and why a farmer should be compelled to plant a dry, woody beet ball, well knowing that before it germinates the soil will be covered with weeds is hard to understand, providing a pratical method of soaking the seed before planting can be seeured.

The German method of soaking the seed in animal urine not only hastens the germination but imparts additional fertilizing properties to the beet ball, thus producing a more thrifty plant, although sometimes killing some of the weaker ones.

Agricultural seience will yet point out a definite method which will not only hasten the germination but henefit the seed without risk of injury.

(3) Another objection offered was that on new Western soil cut worms, beet flies, and other insects are likely to appear when the beet is young, and that, unless a suffieient quantity of seed is drilled in to feed them and still leave enough heets for a stand, they may take all of the beets.

This objection was made to planting a seed every $S$ inehes. If the seeds were drilled in every $1,2,3$, or 4 inches there probubly would be enough to answer all purposes, and when they had served their purpose the superfluous plants could be removed with a hoe. The increased tonnage resulting from the hoeing would far more than pay for its cost.

(4) Still another objection urged was that it would be difficult to feed wet seed through a drill.

This objection could be easily orercome by allowing the surplus or surface moisture on the beet ball to dry ofl, when the beet halls, owing to their increased weight, would run through a drill more ensily than does the dry seed.

Owing to the saving in labor and to the other advantages to be gained by planting single-germ beet balls, I am firmly conrinced that the securing of such a seed will rerolutionize the agricultural end of the beet-sugar business and enable our farmers to produce sugar beets at a greatly reduced cost.

THE INFLUENCE OF FARLY TIINNING.

The influence of early thimning with the present multiple-germ beet ball is of the greatest importance, and late thimning is largely accountalle for the present low tonnage of beets as compared with a maximum crop of $43 \frac{1}{4}$ tons per acre. 
This influence has been thoroughly demonstrated in Germany by the following and other exhaustive experiments most carefully conducted by the best agricultural experts.

The report of these investigations says that four adjoining acres were similarly prepared, planted the same day, and, aside from the time of thinning, all received identical treatment.

The first acre, thimned at the right time, yielded 15 tons.

The second acre, thinned one week later, yielded $13 \frac{1}{2}$ tons.

The third acre, thimned two weeks after the first, yielded 10 tons.

The fourth acre, thinned three weeks after the first, yielded 7 tons.

Estimating the value of the beets at $\$ 5$ per ton, it will be seen that by thinning at the proper time the returns were $\$ 75$ per are. One week's delay meant a loss of $\$ 7.50$ per acre: two weeks' delay caused a loss of $\$ 25$ per acre; while three weeks' delay resulted in a loss of $\$ 40$ per acre, bringing the returns down to $\$ 35$ per acre.

Any further illustrations as to what it means to the farmer to properly thin his beets at the opportune time would seem to be superfluous.

\section{MACHINES hOR PLANTING BEET BALLS.}

As described to the writer, one of the machines which has recently been invented for planting beet balls singly is as follows:

A continuous narrow strip of very thin tissue paper tightly rolled up is placed on a spindle. From this spindle the paper is rerolled on another spindle, the paper in the rewinding process being twisted into a cord or small rope. The machine is set so that as the paper leaves the first spindle and the twisting process begins, beet balls are automatically fed into the curved paper at such intervals as may be desired.

When the spindle is filled with the twisted paper containing the beet halls, it is transferred to an agricultural implement which is pulled across the field by horses. As the implement progresses, it makes a trench into which it unrolls the paper rope. cover's it with earth, and packs it, thus planting a single beet ball in a place.

Perhaps the inventor did not stop to consider that, with the present multiple-germ beet balls the heets would still come up in bunches, and that consequently his process would not eliminate the necessity for thinning, but this would be a practical method of planting the single-germ balls.

I am informed that a dropping drill has recently been perfected which the operator can set so as to drop a single beet ball in a place at any desired distance. This would be a still more simple and less expensive method of planting single-germ balls, but, as with the paperstrip method, would fail to eliminate the necessity for thinning when planting the present multiple-germ ball. 
If there were single-germ beet balls to-day, doubtless within one year there would be a dozen machines on the market any one of which would plant them perfectly.

\section{CRACKING THE BEET BALLS AND SEPARATING THE SEEDS.}

The results to be obtained by breeding a single-germ beet ball can be anticipated to some extent by any grower, inasmuch as it is found that a slight cracking of the beet ball suffices to separate the seeds from the woody matter which incases them. Generally speaking: the larger the beet ball the more seeds it contains, though this is not always the ease. A grinder or cracker set so as to just sufficiently erack the ordinary four-germ ball would miss a large number of two-germ balls, while if set for the average-sized two-germ ball it would injure many of the germs of a four-germ ball; bence it would be wise to first sift the balls into several lots of different sizes, resetting the grinder for each lot, when little or no injury need result from the crushing.

If these cracked balls were not too closely drilled in, they probably could be thinned with a hoe, but in any event the injury done the remaining roots by any process of thimning would not be as great as where severul sprouts come up from a single ball. I believe this method is worthy of careful inrestigation.

As regards cracking the balls into several pieces, but not separating the seeds from the pieces of ball or husk, one of the American field experts writes me that he has seen "a $t$-acre field planted in this same way, the farmer running the seeds through a coffee mill and cracking them, and by planting thus, the seed was well distributed along the row and very few beets came up in bunches. The crop proved a success, and the labor was limited."

\section{CULTIVATION.}

There are two other primary causes of low tonnage where natural conditions are farorable: (1) The lack of deep plowing, proper fertilization, and other preparation of the soil, inchuding the elimination of weed seed, all of which can he easily remedied by the most obtuse farmer who is willing to expend a dollar if thereby he can seeure $\$ 2$ in return; (2) lack of thorough cultivation, which is necessary, not only in order to keep down the weeds but to conserve the moisture and arate the soil.

As to the effect of weeds, certainly every farmer ought to know that every weed that grows takes both noisture and mutriment from the soil, and to that extent injures any near-by vegetable growth. In sugar-beet culture, however, where the farmer is striving for quality as well as quantity, the weeds work a double injury; first, by rohbing 
the plants of nourishment, and, secondly, by cutting down the sugar content through shading.

Not only do frequent hoeing's or cultivations keep the weeds down but stirring the soil permits the air to permeate it, and therein lies one of the great eauses affecting the tomnae. As illustrative of what proper cultivation means, an experiment which was recently conducted in Germany may be cited. Fire adjoining acres were similarly prepared and planted to beets the same day. The treatment thereafter given to the beets was identical, with the exception of hoeing. As the average price of beets in the United States is abont $\$ 5$ per ton, the last three columms in the following table have been added to show what each of these extra hoeings means to the farmer in dollars and cents for every acre so treated:

Nimber of hoeings, yield of brets per acre, yeins from horing.

\begin{tabular}{|c|c|c|c|c|c|}
\hline Acre. & $\begin{array}{l}\text { Number } \\
\text { of hoe- } \\
\text { ings. }\end{array}$ & $\begin{array}{l}\text { Yield per } \\
\text { acre. }\end{array}$ & $\begin{array}{l}\text { Value at } \hat{x} 5 \\
\text { per ton. }\end{array}$ & $\begin{array}{c}\text { Extra re- } \\
5 \text { turn by ad- } \\
\text { ditiollal } \\
\text { hoeings. }\end{array}$ & $\begin{array}{c}\text { Extra re- } \\
\text { turn per } \\
\text { hoeing. }\end{array}$ \\
\hline 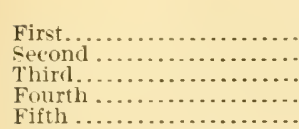 & $\begin{array}{l}1 \\
2 \\
3 \\
4 \\
5\end{array}$ & $\begin{array}{c}\text { Tons. } \\
7 \\
9 \frac{1}{2} \\
10 \frac{1}{2} \\
12 \frac{7}{10} \\
15\end{array}$ & $\begin{array}{r}\$ 35.00 \\
47.50 \\
52.50 \\
63.50 \\
75.00\end{array}$ & $\begin{array}{r}\$ 12.50 \\
17.50 \\
25.50 \\
40.00\end{array}$ & $\begin{array}{r}812.50 \\
8.75 \\
9.50 \\
10.00\end{array}$ \\
\hline
\end{tabular}

In Europe, where labor is cheap and horses are dear, there is not the same incentive to devise implements whereby the work can be done by horses as in the United States where labor is dear and horses are cheap.

The abore experiments refer to ordinary hand hoeing, but with our improved cultivators hand hoeing is not so necessary in this country. Even if it were, it is hard to conceive of an intelligent farmer neglecting his beet fields once he is aware of the immense profit to him through giving his sugar beets proper attention.

\section{EFFECTS OF SUCAR-BEET CULTURE.}

The influence of beet culture on the finmer's land should also be considered.

This ean be clone in no better way than by reproducing that portion of the report of one of our consuls to Germany, which treats of the effect of beet culture in rotation with other crops.

The Germans are not only exceedingly systematic, but very seientific, and the following report of exhaustive experiments most carefully made should serve to disillusionize many who still believe that sugar beets rapidly exhaust the soil. The report is as follows:

A German farm of 625 acres proluced, before the introluction of beet culture, yearly 9,736 bushels of grain in ten years' average. After beet culture was intro- 
duced, with 125 acres yearly to beets, the average yearly grain crop from the remaining 500 acres was 9,870 bushels, or $13 t$ bushels increase. Another farm in the province of Saxony, also of 625 acres, produced before beet culture was introduced, in ten years' average, 13,879 bushels of grain. When five years afterwards 135 acres were planted with beets the grain crop of the remaining 490 acres was 14,365 bushels average, and afterwarls, when yearly 220 acres of beets were planted, the average grain crop from the remaining 405 acres was 14,397 bushels, or 518 bushels more than from the whole 625 acres before beets were raised. Thirty-five other farms of 500 to 1,000 acres each in the province of saxony showed the following results:

Average crops per acre, in pounds.

\begin{tabular}{|c|c|c|c|c|}
\hline Crop. & $\begin{array}{c}\text { Before beet } \\
\text { culture. }\end{array}$ & $\begin{array}{l}\text { After beet } \\
\text { culture. }\end{array}$ & $\begin{array}{l}\text { Inerease } \\
\text { in } \\
\text { pounds. }\end{array}$ & $\begin{array}{l}\text { Per cent } \\
\text { inerease. }\end{array}$ \\
\hline 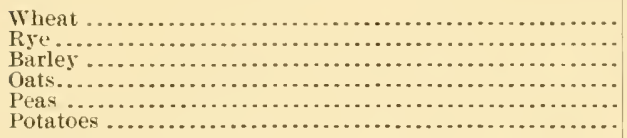 & $\begin{array}{l}1,848 \\
1,456 \\
1,672 \\
1,355 \\
945 \\
6,716\end{array}$ & $\begin{array}{r}2,292 \\
1,672 \\
2,094 \\
1,918 \\
1,834 \\
13,500\end{array}$ & $\begin{array}{r}414 \\
216 \\
122 \\
563 \\
849 \\
6,874\end{array}$ & $\begin{array}{l}24 \\
14.8 \\
25.2 \\
41.5 \\
86 \\
102.3\end{array}$ \\
\hline
\end{tabular}

The arerage beet crop of these farms was $17 \frac{1}{3}$ tons per acre.

The above demonstration shows that the farmer who rotates his beets with other erops does not decrease the productiveness of his land when sown to other crops but, on the contrary, greatly increases its productiveness. The truth is that a good farmer can not measure his profits hy his beet crop alone, but must consider the extra profit which beet culture enables him to make on everything else he grows.

As a matter of fact, the experience in Germany, where erery available acre was under cultivation long prior to the introduction of beet culture, would indicate that the money receired by the farmers for sugar beets is largely profit, inasmuch as since the introduction of beets these districts, as a whole, continue to yield a greater tonnage of other crops ats well as of meat products.

To substantiate this remarkable result I reproduce the following from the report of Mr. M. S. Brewer. American consul-general to Berlin, given under date of Norember 12, 1881 (see page 479 of Beet Sugar Industry and Flax Cultivation in Foreign Countries, State Department. 1891):

Concerning the beet-sugar industry, a few explanatory remarks may not be out of place. How much the influence is appreciated of the cultivation of sugar beets upon agriculture and national welfare may be seen from a passage extracted from a very valnable treatise ly Richard von Kaumamn on sugar industry:

It is an established fart that notwitlostancling the extensive cultivation of sugar beets, no decrease in the yield of cereals has taken place, but it has, on the contrary, angmented by double and treble the amount in the districts where sugar beets are planted, and that at those very places the production of meat is steadily increasing. The growth of sugar beets requires that the soil be tilled to a greater depth, thus adding to the thrift also of other plants to be cultivated later on the same soil. Besides, the remnants or waste left in the manufacture of beet sugar furnish not only 
an excellent food for cattle, but also a fertilizing stuff, dispensing to a considerable extent vith the use of artificial manure. But the profit is also considerable which this industry affords people who work in the sugar manufactories, as they get employment throughout the whole year, during the spring and summer seasons, in the growing and cultivation of the beets, and during the fall and winter in the manufactories.

LOWERING TIHE COST OF STGAI.

The question is, How can the farmer be benefited and now can sugar be produced from beets in America for less money than the present cost?

It has been stated that the time would come when the American beet-sugar factories would produce sugar at a profit at 2 cents per pound. While this is an eventual possibility, it should be patent to all that such a rerolution in cost of production, if brought ahout, must come largely from the agricultural end of the industry.

To-day the factories pay $\$ 5$ for a ton of beets from which they are able to extract an average of 219 pounds of sugar, ${ }^{a}$ the sugar in the beets thus costing them $\$ 2.29$ per 100 pounds.

The average cost of working the beets through the factory is $\$ 3.18 \frac{3}{5}$ ter ton, ${ }^{b}$ or $\$ 1.45$ per 100 pounds of sugar extracted.

The cost of bags or barrels is 10 cents per 100 pounds, while freight, commissions, and other expenses bring the present arerage cost of producing sugar up to $\$ t$ per 100 pounds.

When the American farmer becomes educated to the fact, as recently demonstrated by the Colorado Experiment Station, that beet pulp as compared to other stoek foods is worth $\$ 1.50$ per ton, instead of the sugar manufacturer being obliged to throw his pulp away, the firmer will purehase it at a price based on its actual vahe, the factory proprietor virtually receiving a rebate of 75 cents per ton on the beets he purchases, inasmuch as 2 tons of beets yield 1 ton of pulp. This will mean a reduction of 34 cents per 100 pounds in the cost of the sugar to the factory proprietors, based on the present extration of 219 pounds of sugar per ton of heets.

The utilization of pulp and other by-products will probably make a total saring in this direction of one-half cent per' pound. 'The 1899 arerage "factory expense" of $\$ 3.18^{3}$ per ton of beets can perhaps he eventually reduced to an average of $\$ 2$ per ton, which would make a further reduction of $5 t$ cents per 100 pounds of sugar, resulting in a saring on these two items of $\$ 1.0 t$ per 100 pounds.

The above estimate is based on an extraction of 219 pounds of sugar per ton of beets. When the quality of our beets and the efficiency of our factories are inereased, as will be the case, and thus the arerage

a U. S. Department of Agriculture; Report on the Progress of the Beet-Sugar Industry, 1901, p. 36.

$\checkmark$ Report of Twelfth Census, pp. 543-555. 
extraction is increased to 12 per cent, or 240 poun 00026857375 of beets, the extra 21 pounds of sugar at the present cost of $t$ cents will mean a further reduction in cost of $\delta+$ cents.

If, from the present arerage cost of production of $\$+$ per 100 pounds, these three items are taken-50 cents by utilization of by-products, 54 cents saving in factory expense, and $8 t$ cents in extra sugar-the cost will be brought down to $\$ 2.12$ per 100 pounds. But as the price of sugar goes down, the $S t$ cents for extra extraction should also be cut down. Cutting this in half would leave the cost of producing sugar at $\$ 2.5 \pm$ per 100 pounds with beets at present cost and all of the above economies carried out; hence, even then, sugar can not be produced for 2 cents per pound.

The success of the industry depends upon the fairness of both farmers and factory proprietor's. The price of beets must be so adjusted as to afford each a fair protit, for neither can be expected to work for the sole benefit of the other.

The present New York wholesale price of granulated sugar is $\$ 4.65$ per 100 pounds, and the price of the product necessarily sets a limit to the price which the factories can par for beets.

Looking to a lower cost of production the fact must be recognized that the possible factory economies are limited, while the possible tield economies and improvements are great.

Gradually reducing the difference between the present average yield per aere and the ideal maximum yield of $43 \frac{1}{4}$ tons, the utilization of the by-products, and the elimination of hand labor in the field are the things which must solve the remanning problems of the industry. 



\section{LIBRARY OF CONGRESS}

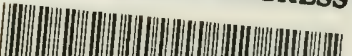

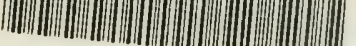

00026857375

\section{Hollinger Corp.}

$$
\mathrm{pH} 8.5
$$

